\title{
Use of non-destructive test methods on Irish hardwood standing trees and small-diameter round timber for prediction of mechanical properties
}

\author{
Daniel F. Llana ${ }^{1,2}$ (D) $\cdot$ Ian Short ${ }^{3} \cdot$ Annette M. Harte $^{1}$ \\ Received: 30 August 2019 / Accepted: 28 April 2020 / Published online: 17 June 2020 \\ (C) INRAE and Springer-Verlag France SAS, part of Springer Nature 2020
}

\begin{abstract}
- Key message Mechanical properties of small-diameter round timber from hardwood thinnings of common alder (Alnus glutinosa (L.) Gaertn.), European ash (Fraxinus excelsior L.), European birch (Betula pendula Roth. and Betula pubescens Ehrh.), and sycamore (Acer pseudoplatanus L.) can be evaluated by non-destructive testing on either standing trees or green logs without wood density determination. Velocity differences between acoustic and resonance methods are influenced by tree species and age. Tree diameter improves the estimation of bending strength but not of stiffness.

- Context There is a need for a reliable, fast, and inexpensive evaluation method to better sort hardwood thinnings according to mechanical properties for use in potential added-value applications.

- Aims The estimation by non-destructive testing of mechanical properties of round small-diameter timber of four hardwood species (common alder, European ash, European birch, and sycamore).

- Methods Acoustic velocity was measured in 38 standing trees and resonance velocity was recorded in green logs from these trees. The logs were then dried and tested in bending. Estimation models to predict mechanical properties from non-destructive testing measurements were developed.

- Results Large differences between velocities from acoustic and resonance techniques were found. Models based on both nondestructive testing velocities together with a species factor are well correlated with bending modulus of elasticity while models including tree diameter are moderately well correlated with bending strength. Inclusion of density in the models does not improve the estimation.

- Conclusion Models based on acoustic measurements on standing trees or resonance on green logs together with tree species and diameter provide reliable estimates of mechanical properties of round timber from hardwood thinnings. This methodology can be easily used for pre-sorting material in the forest.
\end{abstract}

Keywords Bending strength $\cdot$ Broadleaf thinning $\cdot$ Longitudinal frequency $\cdot$ Modulus of elasticity $\cdot$ Stress waves $\cdot$ Wind effect

Handling Editor: Jean-Michel Leban

Contribution of the co-authors Conceptualization: All. Methodology: All. Validation: All. Formal analysis: DFL. Investigation: DFL, IS. Writing — original draft: DFL. Writing — review and editing: DFL, AMH, IS. Supervision: AMH. Funding acquisition: AMH, IS.

Daniel F. Llana

danielfllana@gmail.com

Ian Short

ian.short@teagasc.ie

Annette M. Harte

annette.harte@nuigalway.ie
1 College of Science and Engineering, National University of Ireland Galway, Galway, Ireland

2 Timber Construction Research Group, Universidad Politécnica de Madrid, Madrid, Spain

3 Teagasc, Forestry Development Department, Ashtown Research Centre, Dublin, Ireland 


\section{Introduction}

Guidelines for initial thinning of Irish hardwoods (Short and Radford 2008) recommend the removal of diseased trees, competitors of selected high-quality trees, and trees removed for extraction racks, to favor the growth of selected potential crop trees, maintain stand health and vigor, and provide access for future management. Hawe and Short (2016) have presented a review of best hardwood thinning practices. Although it is still not clear if thinning increases or reduces softwood timber quality (Krajnc et al. 2019a), thinning is always recommended in the case of hardwoods. Trees felled (thinnings) during this initial thinning have small diameters and are considered low quality. In Ireland, hardwood thinnings are mainly used for energy production (Doran 2012; Mockler 2013) and are also used in chipped form in the manufacture of woodbased panels or in the pulp/paper industry (Campion and Short 2016). There is commercial value in seeking to use hardwood thinnings in higher value-added end uses as structural components within the construction industry and to develop its volume use in local rural industry (Wolfe and Moseley 2000; Cumbo et al. 2004; Gorman et al. 2016).

The development of new products utilizing hardwood thinnings requires knowledge of the physical and mechanical properties of the materials. Non-destructive testing techniques are commonly used for estimation of wood properties in forest, sawmill, and existing structures (Ross 2015). Nondestructive testing can be divided in global techniques (ultrasound waves, stress waves, and resonance) and local techniques (probing, coring, and drilling). The former techniques are mainly focused on estimation of static modulus of elasticity (MOE) and bending strength $\left(f_{\mathrm{m}}\right.$, formerly referred to as MOR) (Jayne 1959; Auty and Achim 2008; Íñiguez-González et al. 2019), and the latter on estimation of density (Llana et al. 2018; Fundova et al. 2019; Martínez et al. 2020). It is also common to combine different non-destructive techniques for better estimation results (Divós and Tanaka 1997; Vössing and Niederleithinger 2018). Non-destructive testing has the potential to provide low-cost timber quality assessment, which could be used in the forest to segregate logs into different end use categories. The estimation of mechanical properties of timber from standing trees or green logs has many benefits for growers and processors, as decisions taken at an early stage can result in cost savings.

Much research has been carried out to establish relationships between non-destructive testing measurements and the mechanical properties of wood. Most of this work has focused on softwoods with a relatively small number of studies on hardwoods. Non-destructive testing studies have been carried out at different stages in the wood processing chain including on standing trees, harvested logs, round timber, and sawn timber boards. In the case of hardwood thinnings, the smalldiameter logs are not suitable for sawing because of the low yield and high processing cost. Therefore, the potential end uses of this material are likely to utilize the material in the round. The use of round timber instead of sawn timber presents several advantages. According to Wolfe (2000), round timber represents a more efficient use of material than sawn timber with higher load capacity (up to 5 times more) than timber sawn from it. When round timber is sawn, wood fibers are cut around knots leading to stress concentrations.

The most common non-destructive testing technique used on standing trees for mechanical properties' estimation is based on measurement of stress wave velocity (Wessels et al. 2011). On green logs, longitudinal vibration techniques are more commonly used (Lindström et al. 2002). Several methods for density estimation on standing trees are available including increment boring, penetration resistance, nail withdrawal, and resistance drilling, and these have been evaluated by Gao et al. (2017), who concluded that the drilling resistance method is the fastest and most accurate. On the other hand, it is also the most expensive approach. Furthermore, some authors have estimated MOE using non-destructive testing devices on cores extracted from standing trees (Yang and Fortin 2001; Chen et al. 2015; Desponts et al. 2017).

Most previous research studies have focused on estimation of mechanical properties of sawn timber from measurements on standing trees or logs. Several such studies have focused on softwoods (Ross et al. 1997; Tsehaye et al. 2000; Santaclara and Merlo 2011; Moore et al. 2013; Bertoldo 2014; GilMoreno and Ridley-Ellis 2015; Butler et al. 2017; Krajnc et al. 2019b; Simic et al. 2019). Significantly fewer authors have carried out studies on hardwoods (Casado et al. 2013; Bertoldo 2014). Some authors have tested round timber in bending correlating the results with non-destructive testing measurements. Most of these studies tested small-diameter round timber from thinnings, which according to Wolfe (2000) had a diameter smaller than $230 \mathrm{~mm}$. On smalldiameter timber, determination coefficients $\left(R^{2}\right)$ ranging from 0.60 to 0.75 between global $\mathrm{MOE}$ in bending $\left(\mathrm{MOE}_{\mathrm{m}}\right)$ and longitudinal dynamic modulus of elasticity $\left(\mathrm{Edyn}_{0}\right)$ were reported by Vries and Gard (1998), Wang et al. (2002), and Hermoso et al. (2007), while between local MOE and $\mathrm{Edyn}_{0}$, they ranged from 0.49 to 0.67 (Aira et al. 2019; Vega et al. 2019). According to Krajnc et al. (2019c), who tested three softwood species with diameters from 250 to 410 $\mathrm{mm}$, the estimation of mechanical properties of sawn timber from acoustic velocities on standing trees is better in smalldiameter trees, as no correlation was found in the largerdiameter trees. In addition to longitudinal measurements on small-diameter logs, Wang et al. (2002) measured transversal vibration and found higher estimation $R^{2}$ values using transversal vibration (from 0.85 to 0.95 ).

Pelizan (2004) tested twenty-five 6-m-long roundwood logs of dry lemon-scented gum (Eucalyptus citriodora Hook.) using an ultrasound wave device and three-point 
bending tests. $\mathrm{MOE}_{\mathrm{m}}$ and bending strength for lemon-scented gum could be estimated from the Edyn $\mathrm{E}_{0}$ with $R^{2}$ ranging from 0.48 to 0.83 and from 0.49 to 0.74 , respectively. The $R^{2}$ values were dependent of the relative proportion of sapwood and heartwood, increasing with decreasing proportions of heartwood. Vega et al. (2019) tested 216 small-diameter (60, 80 , and $100 \mathrm{~mm}$ ) cylindrical timber specimens of dry sweet chestnut (Castanea sativa Mill.) using a stress wave device and four-point bending tests. Local $\mathrm{MOE}_{\mathrm{m}}$ from the velocity and $\mathrm{Edyn}_{0}$ was estimated with $R^{2}$ of 0.64 and 0.67 , respectively. The estimates of bending strength were poor.

The main goal of the current research work is to estimate the mechanical properties of round timber from Irish hardwood thinnings using non-destructive testing on standing trees and on green logs, and to determine the best approach to apply in the forest taking into account factors such as stem diameter and species. Three objectives were defined for investigation: first, the influence of measurement position around the tree on non-destructive testing results; second, the differences between stress wave on standing trees and vibration results on green logs; and third, the estimation of mechanical properties from non-destructive testing results..

\section{Materials and methods}

\subsection{Materials}

A total of $38 \operatorname{logs}$ with mid-diameters between 80 and $180 \mathrm{~mm}$ and lengths 25 times the diameter were selected for testing from first and second thinnings of four Irish-grown hardwood species: common alder (Alnus glutinosa (L.) Gaertn.), European ash (Fraxinus excelsior L.), European birch (Betula pendula Roth. and Betula pubescens Ehrh.), and sycamore (Acer pseudoplatanus L.). The trees were chosen from seven stands located in the Republic of Ireland (Table 1). Stand No. 5 had special characteristics because the birch was mixed with other species (European beech (Fagus sylvatica L.) and European oak (Quercus robur L.)). Furthermore, the 1st thinning material was extracted from a flat area on the top of a hill while the 2 nd thinning was midway down the slope of the hillside. Only one log from the bottom part of each tree (butt log) with an overall length of 25 times its mid-diameter was selected, because of the lack of straightness in the top part and the reduced stem diameter. Furthermore, non-destructive testing measurements on butt logs have been found to provide better estimates of MOE than those on upper logs (Tsehaye et al. 2000; Rais et al. 2014).

\subsection{Non-destructive testing experiments}

Two different non-destructive testing approaches were used. The time-of-flight (TOF) of acoustic stress waves over a 1-m length was measured on standing trees at the eight different cardinal and intercardinal points using a TreeSonic (Fakopp, Sopron, Hungary) device and the acoustic velocity was determined. A Mechanical Timber Grader MTG (Brookhuis, Enschede, Netherlands) was then used to determine the fundamental frequency $(f)$ in the longitudinal direction on green logs just after harvesting (Fig. 1). The resonance longitudinal velocity for the logs was calculated using Eq. 1:

$\mathrm{Vel}_{0}=2 \cdot f \cdot L$

where $\mathrm{Vel}_{0}$ is the acoustic velocity in longitudinal direction ( $\mathrm{m}$ $\left.\mathrm{s}^{-1}\right), f$ is the fundamental frequency $(\mathrm{Hz})$, and $L$ is the $\log$ length (m).

Velocities obtained from these measurements were adjusted to a reference moisture content (MC) of $12 \%$ based on the works of Sandoz $(1989,1993)$. The adjustment factor applied was $0.8 \%$ per $1 \% \mathrm{MC}$ below fiber saturation point (FSP). It is well known that the influence of MC on non-destructive testing results is much stronger below than above FSP. According to Sandoz (1993), the influence is at least eight times more on ultrasound velocity. A similar effect was reported by Unterwieser and Schickhofer (2007) and Rais et al. (2020) on longitudinal vibration. For that reason, since green logs had an average MC of $88 \%$, the correction was applied for a reduction in $\mathrm{MC}$ from 30 to $12 \%$. $\mathrm{Edyn}_{0}$ was then calculated from density and velocity previously adjusted to $12 \%$ according to Eq. 2:

$\operatorname{Edyn}_{0}=\rho \cdot \mathrm{Vel}_{0}^{2}$

where $\operatorname{Edyn}_{0}$ is the dynamic MOE in longitudinal direction $(\mathrm{N}$ $\mathrm{m}^{-2}$ ) and $\rho$ is the $\log$ density $\left(\mathrm{kg} \mathrm{m}^{-3}\right)$.

The importance of determining Poisson ratios, for inclusion in the Edyn calculation to accurately determine the MOE, was reported by several authors, who used high-frequency ultrasound devices and small clear specimens (Ozyhar 2013; Niemz and Bachtiar 2017; Suryoatmono 2017; Gonçalves et al. 2019). However, in the present study, Poisson ratios were not taken into account in the Edyn calculation due to high slenderness of the test specimens.

\subsection{Mechanical testing}

After drying the roundwood to a MC below 20\%, four-point bending tests were conducted over a span of 18 times the middiameter to obtain the global $\mathrm{MOE}_{\mathrm{m}}$ and $f_{\mathrm{m}}$. Although there is a specific standard for testing structural round timber (EN14251 2003a), this standard is only designed for local MOE in bending. Therefore, EN408 (2012), which is suitable for rectangular and circular solid timber sections, was followed to determine the $\mathrm{MOE}_{\mathrm{m}}$ (Fig. 1). 
Table 1 Forest stand information characteristics and felled tree mean

\begin{tabular}{|c|c|c|c|c|c|c|c|c|c|}
\hline \multicolumn{7}{|l|}{ Stand } & \multicolumn{3}{|c|}{ Felled trees } \\
\hline $\begin{array}{l}\text { Stand } \\
\text { No. }\end{array}$ & Species & Thinning & $\begin{array}{l}\text { Latitude } \\
\left({ }^{\circ}\right)\end{array}$ & $\begin{array}{l}\text { Longitude } \\
\left({ }^{\circ}\right)\end{array}$ & $\begin{array}{l}\text { Age } \\
\text { (year) }\end{array}$ & $\begin{array}{l}\text { Trees } \\
\text { per ha }\end{array}$ & No. & $\begin{array}{l}\mathrm{DBH} \\
(\mathrm{mm})\end{array}$ & $\begin{array}{l}\text { Height } \\
\text { (m) }\end{array}$ \\
\hline 1 & Ash & $1 \mathrm{st}$ & 54.05133 & -7.30363 & 15 & 2500 & 5 & 127 & 13.6 \\
\hline 2 & Sycamore & $2 \mathrm{nd}$ & 54.05458 & -7.32214 & 23 & 1650 & 3 & 151 & 18.6 \\
\hline 3 & Ash & $2 \mathrm{nd}$ & 53.25189 & -7.15134 & 21 & 1075 & 5 & 133 & 13.8 \\
\hline 4 & Alder & $2 \mathrm{nd}$ & 53.24934 & -7.15756 & 21 & 2650 & 5 & 132 & 12.6 \\
\hline 5 & Birch & $\begin{array}{c}1 \text { st and } \\
2 \text { nd }\end{array}$ & 51.91972 & -8.03055 & 21 & Mix & 5 & 123 & 11.3 \\
\hline 6 & Sycamore & $1 \mathrm{st}$ & 53.47110 & -8.40793 & 15 & 3325 & 5 & 118 & 9.0 \\
\hline 7 & Alder & $1 \mathrm{st}$ & 53.74570 & -8.64617 & 13 & 3475 & 5 & 92 & 8.9 \\
\hline
\end{tabular}

$D B H$, diameter at breast height

\subsection{MC and density determination}

The ovendry method, according to standard EN 13183-1 (2002), was applied to determine the MC in green and dry conditions using disk specimens free of knots and resin pockets according to EN 408 (2012). Furthermore, the mass and dimensions of the disk specimens were recorded to determine the green density.

\section{Results}

\subsection{Influence of measurement position}

Table 2 summarizes mean values of the eight TreeSonic velocity measurements taken at eight cardinal and intercardinal (COV) and $P$ values from analysis of variance (ANOVA).

ANOVA was carried out in order to determine if there are significant differences in TreeSonic velocity around the tree. As all $P$ values in Table 2 are higher than 0.05 , no significant differences were found for the $95 \%$ confident level. However, in the stands No. 3 and 5.1, higher velocities were found in the $225^{\circ}$ measurements (SW) with the values decreasing with position to a minimum in the $45^{\circ}$ (NE) direction (Fig. 2). The differences between highest and lowest velocities are $6.2 \%$ in the case of stand 3 and $4.0 \%$ in the case of 5.1 that is not explained by the variability (Table 2 ). The main reason could be the typical Irish strong wind, which is predominantly from the SW direction. The windward face of the tree is under tension and this is where hardwoods produce reaction wood. These two stands were especially vulnerable to wind action due to their orientation. points around the trees, together with coefficients of variation

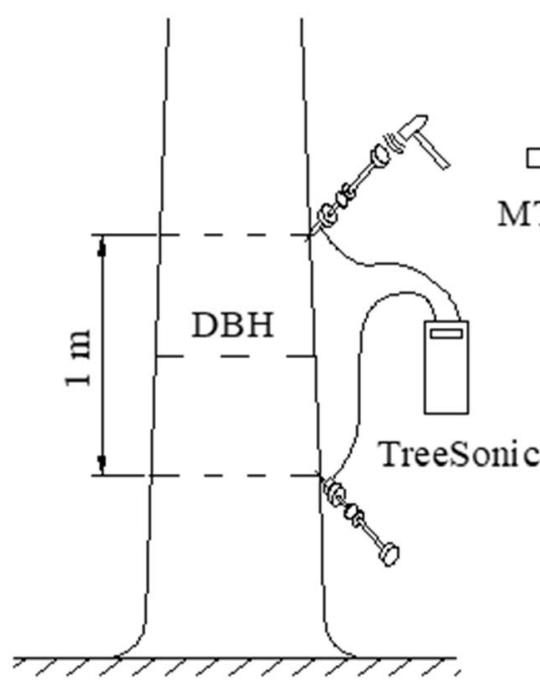

1. Stress waves, standing trees

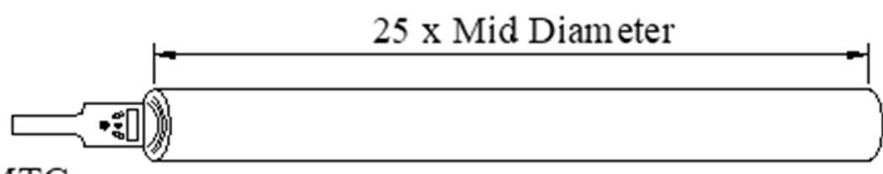

2. Longitudinal vibration, green $\log \mathrm{s}$

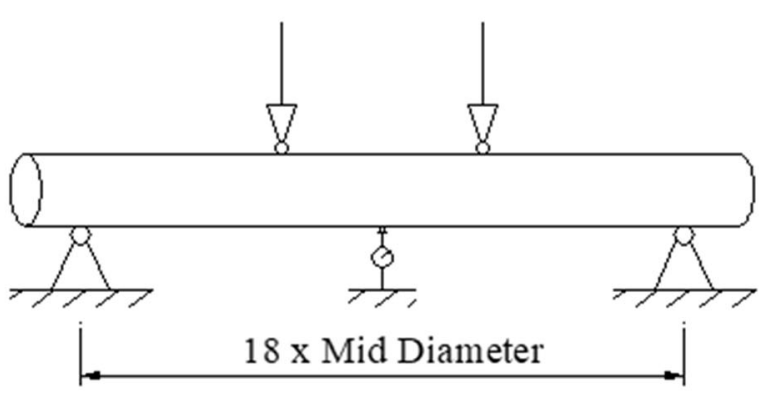

3. Four-point bending test, dry logs

Fig. 1 Measurement set up. (1) On standing trees. (2) On green logs. (3) On dry logs 
Table 2 Mean TreeSonic velocities recorded in eight different positions (cardinal and intercardinal points) around the tree

\begin{tabular}{|c|c|c|c|c|c|c|c|c|c|c|}
\hline \multirow[b]{2}{*}{ Stand } & \multicolumn{8}{|c|}{ Velocity TreeSonic $\mathrm{m} \mathrm{s}^{-1}$} & \multirow[b]{2}{*}{$\begin{array}{l}\mathrm{COV} \\
(\%)\end{array}$} & \multirow[b]{2}{*}{$\begin{array}{l}P \\
\text { value }\end{array}$} \\
\hline & $\mathrm{N} 0^{\circ}$ & $\begin{array}{l}\mathrm{NE} \\
45^{\circ}\end{array}$ & $\begin{array}{l}\mathrm{E} \\
90^{\circ}\end{array}$ & $\begin{array}{l}\mathrm{SE} \\
135^{\circ}\end{array}$ & $\begin{array}{l}\mathrm{S} \\
180^{\circ}\end{array}$ & $\begin{array}{l}\mathrm{SW} \\
225^{\circ}\end{array}$ & $\begin{array}{l}\text { W } \\
270^{\circ}\end{array}$ & $\begin{array}{l}\text { NW } \\
315^{\circ}\end{array}$ & & \\
\hline 1 & 4116 & 4112 & 4161 & 4135 & 4208 & 4214 & 4142 & 4142 & 0.9 & 0.995 \\
\hline 2 & 4074 & 4106 & 4056 & 4028 & 3966 & 3975 & 4031 & 4075 & 1.1 & 0.949 \\
\hline 3 & 4189 & 4147 & 4142 & 4195 & 4289 & 4398 & 4258 & 4308 & 2.0 & 0.473 \\
\hline 4 & 3675 & 3716 & 3690 & 3757 & 3715 & 3702 & 3795 & 3718 & 1.0 & 0.989 \\
\hline 5.1 & 4085 & 4074 & 4110 & 4163 & 4180 & 4236 & 4215 & 4138 & 1.3 & 0.539 \\
\hline 5.2 & 4013 & 3979 & 3916 & 3911 & 3952 & 3955 & 4025 & 4051 & 1.2 & 0.969 \\
\hline 6 & 3125 & 3119 & 3104 & 3105 & 3092 & 3122 & 3097 & 3092 & 0.4 & 1.000 \\
\hline 7 & 3209 & 3162 & 3188 & 3181 & 3197 & 3224 & 3225 & 3155 & 0.8 & 0.968 \\
\hline
\end{tabular}

3.2 Differences between results from different nondestructive testing devices

Table 3 summarizes and compares the mean velocities obtained using the TreeSonic and the MTG devices.

As expected, stress wave velocities (TreeSonic) are higher than those determined using longitudinal vibration (MTG) and on average are $18.6 \%$ higher (Table 3). Furthermore, these differences are expected to be even greater if the stress waves are measured from end-to-end as the longitudinal vibration was measured, because end-to-end velocities are always higher than surface velocities. Arriaga et al. $(2017,2019)$ reported velocities up to $4.4 \%$ higher in sawn timber. Table 3 also shows differences between velocity values from 1 st and 2 nd thinnings for both devices. Performing a $t$ test, significant differences between 1st and 2nd thinning velocities were found in the case
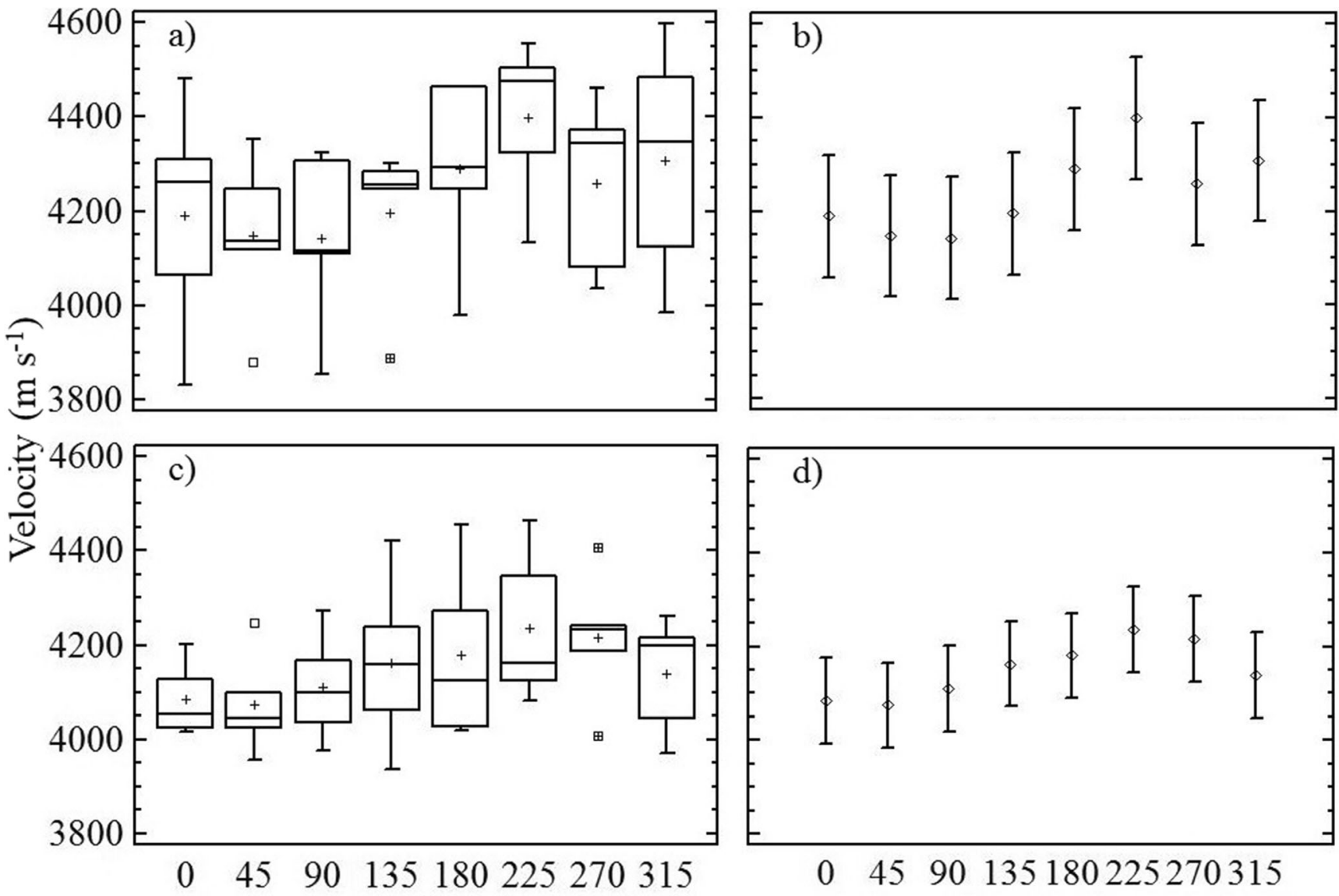

\section{Cardinal direction angle $\left({ }^{\circ}\right)$}

Fig. 2 ANOVA box and whisker plot and mean test for TreeSonic velocity around trees: (a) and (b) stand 3 ash; (c) and (d) stand 5.1 birch 
of alder and sycamore, but not in the case of ash and birch (Fig. 3 ). Non-destructive testing velocities are higher in the 2 nd thinning (except in birch) as was expected because 1st thinning trees have a larger proportion of juvenile wood compared with those from 2nd thinnings. However, densities are lower in the second thinning (except in birch). As was explained earlier, the birch stand was the same for 1st and 2nd thinnings and was mixed with two other species. Furthermore, 1st and 2nd thinnings in all species (except in birch) are from different stands so that other factors such as soil type and wind exposure may have an influence on the properties.

\subsection{Mechanical properties' estimation}

Table 4 shows mechanical properties obtained from four-point bending tests performed in the laboratory on dry logs and density obtained from disks. $\mathrm{MOE}_{\mathrm{m}}$ and density were adjusted to $12 \% \mathrm{MC}$ according to EN384 (2018).

In order to estimate the mechanical properties from nondestructive testing measurements, regression models were developed to estimate static $\mathrm{MOE}_{\mathrm{m}}$ from velocity and $\mathrm{Edyn}_{0}$ obtained from TreeSonic measurements on standing trees and from MTG velocity and $\mathrm{Edyn}_{0}$ on green logs (Fig. 4).

Several other variables, such as species factor, density, $\mathrm{DBH}$, number of annual rings, and thinning parameters, were included in the estimation models in order to improve the prediction of $\mathrm{MOE}_{\mathrm{m}}$. Only the species factor resulted in higher coefficients of determination. The final model is given in Eq. 3 and the model coefficients are presented in Table 5.

$$
\begin{aligned}
\mathrm{MOE}_{\mathrm{m}}= & a \cdot\left(\mathrm{Vel}_{0} \text { or } \mathrm{Edyn}_{0}\right)+b \cdot \text { Zald }+c \cdot \text { Zash }+d \\
& \cdot \text { Zbir }+0 \cdot \mathrm{Zsyc}+e
\end{aligned}
$$

where $\mathrm{MOE}_{\mathrm{m}}$ is the static global modulus of elasticity in bending $\left(\mathrm{N} \mathrm{mm}^{-2}\right), \mathrm{Vel}_{0}$ is the velocity obtained from TOF or longitudinal frequency $\left(\mathrm{m} \mathrm{s}^{-1}\right), \mathrm{Edyn}_{0}$ is the dynamic modulus of elasticity determined from Eq. 2, and Zald, Zash, Zbir, and Zsyc are constants for alder, ash, birch, and sycamore, respectively, which have a value of 1 for the tree in question and 0 otherwise.

Since the $P$ values in the ANOVA table are less than 0.05 , there is a statistically significant relationship between the $\mathrm{MOE}_{\mathrm{m}}$ and the explanatory variables at the $95 \%$ confidence level. All the models presented similar $R^{2}$ being slightly higher using velocity. Therefore, $\mathrm{MOE}_{\mathrm{m}}$ can be estimated on standing trees using TreeSonic velocity without the necessity to estimate the wood density in the forest. This is especially important in thinnings in order to minimize the timber quality evaluation costs.

Using the same approach used for developing $\mathrm{MOE}_{\mathrm{m}}$ models, estimation models were also developed for $f_{\mathrm{m}}$. In this case, the predictive power of the model was improved when species factor and $\log$ mid-diameter were included. The $f_{\mathrm{m}}$ model is given in Eq. 4 with the model coefficients given in Table 6 .

$$
\begin{aligned}
f_{\mathrm{m}}= & a \cdot\left(\mathrm{Vel}_{0} \text { or } \operatorname{Edyn}_{0}\right)+b \cdot \text { Zald }+c \cdot \text { Zash }+d \cdot \text { Zbir } \\
& +0 \cdot Z_{s y c}+e \cdot \varnothing_{\text {mid }}+f
\end{aligned}
$$

where $f_{\mathrm{m}}$ is the bending strength $\left(\mathrm{N} \mathrm{mm}^{-2}\right)$ and $\varnothing_{\text {mid }}$ is the log mid-diameter ( $\mathrm{mm})$.

\section{Discussion}

\subsection{Influence of measurement position}

In the present work, no significant differences were found between the eight TreeSonic velocities around the trees.
Table 3 Non-destructive testing

\begin{tabular}{|c|c|c|c|c|c|c|}
\hline \multirow[t]{2}{*}{ Species } & \multirow[t]{2}{*}{ Thinning } & \multicolumn{2}{|c|}{ Velocity TreeSonic } & \multicolumn{2}{|l|}{ Velocity MTG } & \multirow[t]{2}{*}{ Velocity difference (\%) } \\
\hline & & Mean $\left(\mathrm{m} \mathrm{s}^{-1}\right)$ & $\operatorname{COV}(\%)$ & $\operatorname{Mean}\left(\mathrm{m} \mathrm{s}^{-1}\right)$ & $\operatorname{COV}(\%)$ & \\
\hline \multirow[t]{3}{*}{ Alder } & $1 \mathrm{st}$ & 3609 & 4.6 & 3053 & 7.1 & 18.2 \\
\hline & 2 nd & 4254 & 5.3 & 3419 & 3.1 & 24.4 \\
\hline & Both & 3931 & 9.6 & 3257 & 7.5 & 20.7 \\
\hline \multirow[t]{3}{*}{ Ash } & $1 \mathrm{st}$ & 4738 & 4.5 & 4088 & 5.5 & 15.9 \\
\hline & 2 nd & 4928 & 5.2 & 4185 & 2.7 & 17.8 \\
\hline & Both & 4833 & 5.3 & 4136 & 4.5 & 16.9 \\
\hline \multirow[t]{3}{*}{ Birch } & $1 \mathrm{st}$ & 4734 & 2.7 & 3877 & 5.8 & 22.1 \\
\hline & 2 nd & 4635 & 4.9 & 3704 & 8.4 & 25.1 \\
\hline & Both & 4684 & 4.1 & 3791 & 7.5 & 23.6 \\
\hline \multirow[t]{3}{*}{ Sycamore } & $1 \mathrm{st}$ & 3537 & 9.4 & 3139 & 5.0 & 12.7 \\
\hline & 2 nd & 4661 & 7.3 & 4034 & 5.5 & 15.5 \\
\hline & Both & 3959 & 16.1 & 3475 & 13.5 & 13.9 \\
\hline All together & & 4372 & 12.9 & 3686 & 12.3 & 18.6 \\
\hline
\end{tabular}
acoustic velocity on standing trees (TreeSonic) and green logs (MTG) 
Fig. 3 ANOVA mean test for TreeSonic velocities of 1 st and 2nd thinnings: Al, alder; A, ash; B, birch; S, sycamore

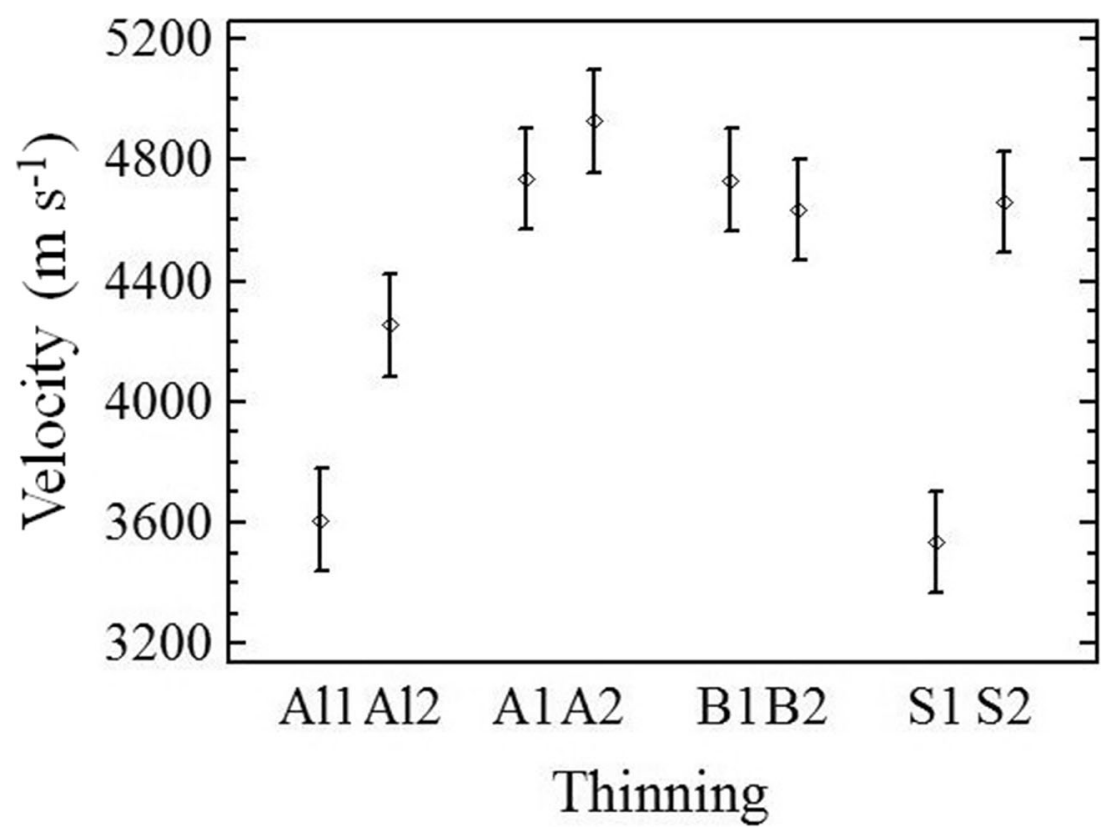

\subsection{Comparison of non-destructive results on stand- ing trees and green logs}

Another important issue affecting non-destructive testing measurements is the higher velocities obtained from acoustic methods in comparison with resonance methods. This issue is well known in sawn timber (Haines et al. 1996; Íñiguez 2007; Llana et al. 2016) but has been less studied for stress waves devices on standing trees and resonance devices on green logs. In this study, velocity values ranging from 12.7 to $25.1 \%$ higher were found using stress waves compared with resonance methods. Several authors found a similar effect in softwoods with
Table 4 MC and mechanical properties obtained by four-point bending test on dry logs

\begin{tabular}{|c|c|c|c|c|c|c|c|c|c|}
\hline \multirow[t]{2}{*}{ Species } & \multirow[t]{2}{*}{ Thinning } & \multicolumn{2}{|l|}{$\mathrm{MC}$} & \multicolumn{2}{|l|}{$\mathrm{MOE}_{\mathrm{m}}$} & \multicolumn{2}{|l|}{$f_{\mathrm{m}}$} & \multicolumn{2}{|l|}{ Density } \\
\hline & & $\begin{array}{l}\text { Mean } \\
(\%)\end{array}$ & $\begin{array}{l}\mathrm{COV} \\
(\%)\end{array}$ & $\begin{array}{l}\text { Mean }(\mathrm{N} \\
\left.\mathrm{mm}^{-2}\right)\end{array}$ & $\begin{array}{l}\mathrm{COV} \\
(\%)\end{array}$ & $\begin{array}{l}\text { Mean }(\mathrm{N} \\
\left.\mathrm{mm}^{-2}\right)\end{array}$ & $\begin{array}{l}\mathrm{COV} \\
(\%)\end{array}$ & $\begin{array}{l}\text { Mean } \\
\left(\mathrm{kg} \mathrm{m}^{-3}\right)\end{array}$ & $\begin{array}{l}\mathrm{COV} \\
(\%)\end{array}$ \\
\hline \multirow[t]{3}{*}{ Alder } & $1 \mathrm{st}$ & 12.6 & 5.2 & 5735 & 10.5 & 61.83 & 16.8 & 498 & 7.1 \\
\hline & 2nd & 15.1 & 10.4 & 7740 & 11.9 & 51.79 & 24.4 & 481 & 4.6 \\
\hline & Both & 13.8 & 12.5 & 6738 & 18.8 & 56.81 & 22.2 & 489 & 6.3 \\
\hline \multirow[t]{3}{*}{ Ash } & $1 \mathrm{st}$ & 18.2 & 8.1 & 10162 & 16.9 & 65.11 & 11.1 & 668 & 6.9 \\
\hline & 2nd & 18.4 & 9.4 & 9435 & 12.6 & 60.86 & 11.5 & 659 & 7.3 \\
\hline & Both & 18.3 & 8.8 & 9799 & 15.5 & 62.99 & 11.8 & 664 & 7.2 \\
\hline \multirow[t]{3}{*}{ Birch } & $1 \mathrm{st}$ & 19.8 & 10.1 & 8076 & 13.8 & 47.33 & 18.9 & 592 & 3.9 \\
\hline & $2 \mathrm{nd}$ & 18.8 & 9.6 & 7519 & 13.2 & 49.75 & 14.3 & 606 & 2.1 \\
\hline & Both & 19.3 & 10.2 & 7797 & 14.0 & 48.54 & 16.9 & 599 & 3.3 \\
\hline \multirow[t]{3}{*}{ Sycamore } & $1 \mathrm{st}$ & 10.3 & 8.0 & 6391 & 22.0 & 43.90 & 13.9 & 560 & 5.1 \\
\hline & 2nd & 14.4 & 9.9 & 8918 & 12.0 & 56.02 & 11.5 & 542 & 8.3 \\
\hline & Both & 11.9 & 19.1 & 7339 & 24.2 & 48.45 & 17.7 & 553 & 6.6 \\
\hline All together & & 16.0 & 22.2 & 7949 & 23.1 & 54.50 & 20.7 & 578 & 12.8 \\
\hline
\end{tabular}




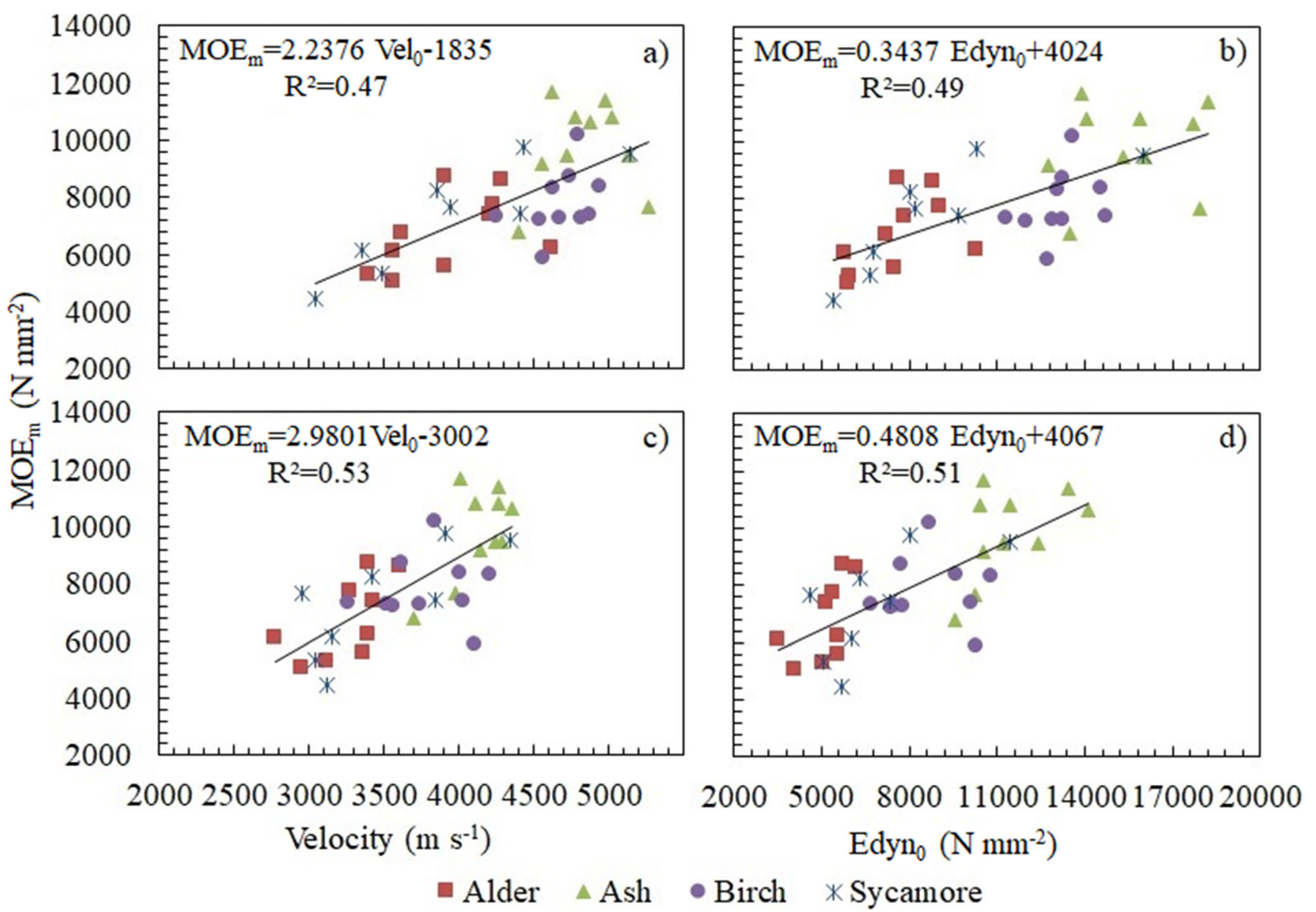

Fig. 4 Linear regressions between static $\mathrm{MOE}_{\mathrm{m}}$ and (a) TreeSonic velocity, (b) TreeSonic Edyn ${ }_{0}$, (c) MTG velocity, and (d) MTG Edyn 0

variable differences. From the smallest to the highest, the differences were as follows: $9.5 \%$ Yin et al. (2010); $11.2 \%$ Simic et al. (2019); $12 \%$ Grabianowski et al. (2006); from 8.7 to $17.5 \%$ Chauhan and Walker (2006); from 16 to $31 \%$ Lasserre et al. (2007); 32\% Mora et al. (2009); from 7 to $36 \%$ Wang et al. (2007). Furthermore, in hardwoods (Eucalyptus sp.), $20 \%$ was reported by Bertoldo (2014). Various theories have been used to explain these differences. Chauhan and Walker (2006) and Grabianowski et al. (2006) attributed the differences to the fact that stress wave devices measure outerwood containing more mature wood, while resonance devices assess the whole cross section. According to Bertoldo and Gonçalves (2015), acoustoelasticity could also explain these differences based on the variation in the velocity due to loading conditions: standing trees support their weight, while logs are free of loads. Wang et al. (2007) suggested that the differences are due to the type of wave propagation: dilatational waves in the case of TOF measurements on standing trees and one-dimensional longitudinal waves in the case of logs. Additionally, they found a smaller difference in small-diameter trees because stress waves would propagate in those cases more as onedimensional longitudinal waves. Chauhan and Walker (2006) also found less difference in young trees. This is in agreement with the results of the present work, where lower velocity differences were found in the 1 st than in 2nd thinning. Finally, according to Wang (2013), different TOF measurement devices used on standing trees may have different algorithms and trigger settings, making it
Table 5 Coefficients of the regression model for $\mathrm{MOE}_{\mathrm{m}}$ estimation (Eq. 3)

\begin{tabular}{llllllll}
\hline Variable & $\mathrm{a}$ & $\mathrm{b}$ & $\mathrm{c}$ & $\mathrm{d}$ & $\mathrm{e}$ & $\mathrm{R} 2$ & $\mathrm{P}$-value \\
\hline Vel $_{0}$ TreeSonic & 2.0500 & -544.94 & 667.72 & -1028.35 & -776.64 & 0.59 & 0.000 \\
Edyn $_{0}$ TreeSonic & 0.3735 & -126.02 & -23.09 & -1139.55 & 4022.53 & 0.56 & 0.000 \\
Vel $_{0}$ MTG & 2.5508 & -42.33 & 772.00 & -347.97 & -1524.13 & 0.58 & 0.000 \\
Edyn $_{0}$ MTG & 0.4702 & 181.80 & 309.48 & -414.97 & 4136.83 & 0.53 & 0.000 \\
\hline
\end{tabular}


Table 6 Coefficients of the regression model for bending strength estimation (Eq. 4)

\begin{tabular}{lllllllll}
\hline Variable & $a$ & $b$ & $c$ & $d$ & $e$ & $f$ & $R^{2}$ & $P$ value \\
\hline Vel $_{0}$ TreeSonic & 0.0049 & 4.60 & 10.18 & -5.04 & -0.21 & 56.11 & 0.44 & 0.002 \\
Edyn $_{0}$ TreeSonic & 0.0015 & 6.28 & 4.63 & -7.82 & -0.21 & 62.95 & 0.47 & 0.001 \\
Vel $_{0}$ MTG & 0.0091 & 5.46 & 8.46 & -4.28 & 0.20 & 42.90 & 0.46 & 0.001 \\
Edyn $_{0}$ MTG & 0.0021 & 7.26 & 5.02 & -5.09 & -0.18 & 57.65 & 0.48 & 0.001 \\
\hline
\end{tabular}

difficult to compare results between authors using different devices.

\subsection{Estimation of mechanical properties from non- destructive testing}

Table 7 presents results from several authors, who used nondestructive testing devices on standing trees or logs. The bending tests were carried out either on the logs in roundwood form or on timber sawn from the logs.

In the present study, the $\mathrm{MOE}_{\mathrm{m}}$ of round timber estimated from $\mathrm{Edyn}_{0}$ and velocity had coefficients of determination $R^{2}$ of 0.56 and 0.59 , respectively, in the case of the TreeSonic, and 0.53 and 0.58 in the case of the MTG. For bending strength estimation, $R^{2}$ varied from 0.44 to 0.48 for both devices. The $R^{2}$ values obtained are relatively low. The main reason could be the small number of data points for each species, as only five trees were tested on each kind, when it was possible. In any case, the $R^{2}$ values obtained are not too far away from those reported by other authors using larger samples (Table 7), e.g., Vega et al. (2019) obtained $R^{2}$ values from 0.64 to 0.67 when testing 216 small-diameter round sweet chestnut using a Microsecond Timer (equivalent to TreeSonic). Table 7 presents the results from other studies. It should be taken into account that it is difficult to compare results with other authors as there is a great disparity of methods used (different devices, different species, standing trees, green or dry logs, large or small diameter, testing round shape or sawn timber). Therefore, a great disparity of $R^{2}$ results was found (from 0.02 to 0.83 for $\mathrm{MOE}_{\mathrm{m}}$ and from 0.03 to 0.81 for $f_{\mathrm{m}}$ ). In agreement with other works, the $\mathrm{MOE}_{\mathrm{m}}$ estimation models presented here have higher determination coefficients than those for $f_{\mathrm{m}}$. Simic et al. (2019) found better mechanical properties' estimation from green logs' resonance than from standing trees' TOF velocities; in the present study, the $R^{2}$ values for the estimation models were similar between the two techniques as was reported by Moore et al. (2013). Simic et al. (2019) presented far higher $R^{2}$ values and Vega et al. (2019) slightly higher $R^{2}$ values when estimation was carried out from $\mathrm{Edyn}_{0}$ than from velocity, while in the present work, slightly higher $R^{2}$ values were found using velocity than using $\operatorname{Edyn}_{0}$. However, Simic et al. (2019) estimated mechanical properties of sawn timber while in Vega et al. (2019) and the present work, small-diameter roundwood mechanical properties were estimated. It appears that for small-diameter roundwood, estimation from velocity and Edyn $_{0}$ is similar. Furthermore, Table 7 does not show a difference in the coefficient of determination between softwoods and hardwoods.

Several studies have shown that estimation models and grading systems based on non-destructive testing measurements were improved by inclusion of the following parameters: diameter (Wang et al. 2004; Zhang et al. 2011; Ruy et al. 2018), ring width (Moore et al. 2013), height and basal area (Merlo et al. 2014). Diameter was found to increase the $R^{2}$ values from 0.30 to 0.44 in the $f_{\mathrm{m}}$ estimation models of the current study. However, the listed parameters had no significant influence in the $\mathrm{MOE}_{\mathrm{m}}$ estimation models.

\section{Conclusions}

No significant differences were found in stress wave velocities from the eight measurements around the tree perimeter. However, higher velocities (from 4 to $6 \%$ ) were found in some stands in the predominant wind direction associated with reaction wood.

Higher velocities were found using stress waves on standing trees than using resonance on green logs (from 12.7 to $25.1 \%$ ). This difference depends on the species and is greater in the second than in first thinning. Nevertheless, the estimation of mechanical properties $\left(\mathrm{MOE}_{\mathrm{m}}\right.$ and $f_{\mathrm{m}}$ ) of final dry roundwood is not affected as similar determination coefficients were found using stress waves or resonance. Prediction of mechanical properties was improved by including species as a factor, and in the case of $f_{\mathrm{m}}$, also stem diameter ( $\left.\mathrm{MOE}_{\mathrm{m}} R^{2} 0.59 ; f_{\mathrm{m}} R^{2} 0.44\right)$. Estimation model results from acoustic velocity data (no requirement for wood density measurement) were not significantly different from those derived from $\mathrm{Edyn}_{0}$ (that require wood density measurement) and, therefore, represent a consequent saving in time and cost.

Either stress waves on standing trees or resonance on green logs can be used to evaluate mechanical properties in the forest. Both are fast, reliable, and inexpensive methods of presorting material based on quality. In the case of stress waves, it is recommended to use two diametrically opposite 
Table 7 Determination coefficients of mechanical properties (MOE and bending strength) estimation models using non-destructive testing devices from several authors

\begin{tabular}{|c|c|c|c|c|c|c|}
\hline Device & Variable & $\mathrm{MOE}_{\mathrm{m}} R^{2}$ & $f_{\mathrm{m}} R^{2}$ & Species* & Bending test & Author \\
\hline GrindoSonic MK5 $5^{(\mathrm{v})}$ & $\operatorname{Edyn}_{0}$ & $\begin{array}{l}0.72 \\
0.76\end{array}$ & $\begin{array}{l}0.58 \\
-\end{array}$ & $\begin{array}{l}\text { Japanese larch } \\
\text { Douglas fir }\end{array}$ & Roundwood & Vries and Gard 1998 \\
\hline Accelerometer ${ }^{(\mathrm{v})}$ & $\operatorname{Edyn}_{0}$ & $\begin{array}{l}0.60 \\
0.75\end{array}$ & - & $\begin{array}{l}\text { Jack pine } \\
\text { Red pine }\end{array}$ & & Wang et al. 2002 \\
\hline Sylvatest Duo ${ }^{(\mathrm{u})}$ & $\operatorname{Edyn}_{0}$ & $0.48-0.83$ & $0.49-0.74$ & Lemon-scented gum ${ }^{(\mathrm{H})}$ & & Pelizan $2004^{(1)}$ \\
\hline Sylvatest Duo ${ }^{(\mathrm{u})}$ & $\operatorname{Edyn}_{0}$ & 0.68 & - & Salzmann pine & & Hermoso et al. 2007 \\
\hline $\mathrm{PLG}^{(\mathrm{v})}$ & Frequency & 0.43 & - & Spanish juniper & & Villanueva 2009 \\
\hline Microsecond Timer ${ }^{(\mathrm{s})}$ & $\operatorname{Edyn}_{0}$ & $\begin{array}{l}0.57^{(\mathrm{L})} \\
0.49^{(\mathrm{L})}\end{array}$ & $\begin{array}{l}0.57 \\
0.45\end{array}$ & $\begin{array}{l}\text { Salzmann pine } \\
\text { Scots pine }\end{array}$ & & Aira et al. 2019 \\
\hline Microsecond Timer ${ }^{(\mathrm{s})}$ & $\begin{array}{l}\text { Velocity } \\
\text { Edyn }_{0}\end{array}$ & $\begin{array}{l}0.64^{(\mathrm{L})} \\
0.67^{(\mathrm{L})}\end{array}$ & - & Sweet chestnut ${ }^{(\mathrm{H})}$ & & Vega et al. 2019 \\
\hline Hitman ST300 ${ }^{(\mathrm{s})}$ & Velocity & 0.53 & 0.59 & Scots pine & Sawn timber & Auty and Achim $2008^{(2)}$ \\
\hline Hitman HM200(v) & Velocity & 0.73 & - & Maritime pine & & Santaclara and Merlo 2011 \\
\hline Microsecond Timer ${ }^{(s)}$ & Velocity & 0.50 & - & Black poplar ${ }^{(\mathrm{H})}$ & & Casado et al. 2013 \\
\hline $\begin{array}{l}\text { IML Hammer }^{(\mathrm{s})} \\
\text { Hitman HM200(v) }^{(\mathrm{v})}\end{array}$ & $\begin{array}{l}\operatorname{Edyn}_{0} \\
\operatorname{Edyn}_{0}\end{array}$ & $\begin{array}{l}0.49-0.83 \\
0.45-0.80\end{array}$ & $\begin{array}{l}0.81 \\
0.68\end{array}$ & Sitka spruce & & Moore et al. 2013 \\
\hline $\begin{array}{l}\text { USLab }^{(\mathrm{u})} \\
\text { Hitman ST300 }^{(\mathrm{s})}\end{array}$ & $\begin{array}{l}\text { Velocity } \\
\text { Velocity }\end{array}$ & $\begin{array}{l}0.64 \\
0.78\end{array}$ & $\begin{array}{l}0.67 \\
0.38\end{array}$ & $\begin{array}{l}\text { Daintree stringybark }{ }^{(\mathrm{H})} \\
\text { Lemon-scented gum }^{(\mathrm{H})} \\
\text { Saligna gum } \\
\text { Maritime pine }\end{array}$ & & Bertoldo $2014^{(1)}$ \\
\hline $\begin{array}{l}\text { TreeSonic }^{(\mathrm{s})} \\
\text { Hitman HM200 }^{(\mathrm{v})}\end{array}$ & $\begin{array}{l}\text { Edyn }_{0} \\
\text { Velocity }\end{array}$ & $\begin{array}{l}0.27-0.57 \\
0.63\end{array}$ & - & $\begin{array}{l}\text { Noble fir } \\
\text { Norway spruce } \\
\text { Western hemlock } \\
\text { Western red cedar }\end{array}$ & & Gil-Moreno and Ridley-Ellis 2015 \\
\hline Hitman HM200 (v) & Velocity & $0.49-0.67$ & 0.20 & Loblolly pine & & Butler et al. 2017 \\
\hline TreeSonic $^{(\mathrm{s})}$ & Velocity & $\begin{array}{l}0.43 \\
0.05 \\
0.02\end{array}$ & $\begin{array}{l}0.29 \\
0.03 \\
0.04\end{array}$ & $\begin{array}{l}\text { Douglas fir } \\
\text { Norway spruce } \\
\text { Sitka spruce }\end{array}$ & & Krajnc et al. 2019c \\
\hline Hitman ST300(s) & $\begin{array}{l}\text { Velocity } \\
\text { Edyn }_{0}\end{array}$ & $\begin{array}{l}0.41 \\
0.55\end{array}$ & $\begin{array}{l}0.27 \\
0.47\end{array}$ & Sitka spruce & & Simic et al. 2019 \\
\hline $\mathrm{MTG}^{(\mathrm{v})}$ & $\begin{array}{l}\text { Frequency } \\
\text { Edyn }_{0}\end{array}$ & $\begin{array}{l}0.47 \\
0.66\end{array}$ & $\begin{array}{l}0.28 \\
0.50\end{array}$ & & & \\
\hline
\end{tabular}

Kind of device used: ${ }^{(\mathrm{s})}$ stress waves, ${ }^{(\mathrm{u})}$ ultrasound waves, ${ }^{(\mathrm{v})}$ vibration

${ }^{(\mathrm{H})}$ Hardwood species

${ }^{(\mathrm{L})}$ Local MOE in bending

(1) Three-point bending test

${ }^{(2)}$ Small clear specimens

*Species' common names according to standard EN13556 (2003b) when possible, and when not according to Miller and Ilic (1992)

measurements or a single measurement perpendicular to the predominant wind direction.

The results, based on 38 logs from four hardwood species, require validation with a larger sample. An appropriate methodology for the evaluation of the mechanical properties of hardwood thinnings using non-destructive testing, including the identification of the relevant forestry parameters that should also be taken into account, has been developed and can be applied in future studies.

Acknowledgments The authors would like to thank Mr. Jerry Campion and Mr. Derek Gibson from Teagasc, for their technical support in the fieldwork; private landowners for freely supplying the material; and Mr. Conor Fahy from ECC Teoranta for kindly providing access to their kiln-drying facilities. Furthermore, Ms. Rachel Keane, Mr. Peter Fahy, and Mr. Colm Walsh from the National University of Ireland Galway for their helpful technical assistance in the laboratory testing.

Funding information Department of Agriculture, Food and the Marine. DAFM research funding program. Project 15C666: Exploitation And Realisation of Thinnings from Hardwoods (E.A.R.T.H.).

Data availability The datasets generated during the current study are available from the corresponding author on reasonable request. 


\section{Compliance with ethical standards}

Conflict of interest The authors declare that they have no conflict of interest.

\section{References}

Aira JR, Villanueva JL, Lafuente E (2019) Visual and machine grading of small diameter machined round Pinus sylvestris and Pinus nigra subsp. salzmannii wood from mature Spanish forests. Mater Struct 52:32. https://doi.org/10.1617/s11527-019-1330-4

Arriaga F, Llana DF, Esteban M, Íniguez-González G (2017) Influence of length and sensor positioning on acoustic time-of-flight (ToF) measurement in structural timber. Holzforschung 71(9):713-723. https://doi.org/10.1515/hf-2016-0214

Arriaga F, Montón J, Bobadilla I, Llana DF (2019) Influence of length on acoustic time-of-flight $(\mathrm{ToF})$ measurement in built-in structures of Norway spruce timber. Holzforschung 73(4):339-352. https://doi. org/10.1515/hf-2018-0122

Auty D, Achim A (2008) The relationship between standing tree acoustic assessment and timber quality in Scots pine and the practical implications for assessing timber quality from naturally regenerated stands. Forestry 81(4):475-486. https://doi.org/10.1093/forestry/ cpn015

Bertoldo C (2014) Propriedades de resistência e de rigidez da madeira obtidas a partir da avaliação acústica na árvore [Predicting of strength and stiffness of wood using acoustic measurement in trees]. $\mathrm{PhD}$ Dissertation. Faculdade de Engenharia Agrícola. Universidade Estadual de Campinas, SP, Brazil. $146 \mathrm{p}$

Bertoldo C, Gonçalves R (2015) Influence of measurement position, tree diameter, and bulk wood density on models that predict wave propagation velocity in logs according to the velocity in trees. For Prod $\mathrm{J}$ 65(3):166-172. https://doi.org/10.13073/FPJ-D-14-00012

Butler MA, Dahlen J, Eberhardt TL, Montes C, Antony F, Daniels RF (2017) Acoustic evaluation of loblolly pine tree- and lumber-length logs allows for segregation of lumber modulus of elasticity, not for modulus of rupture. Ann For Sci 74:20. https://doi.org/10.1007/ s13595-016-0615-9

Campion J, Short I (2016) The uses of small-diameter roundwood from 1st and 2nd thinnings. Report. $44 \mathrm{p}$

Casado M, Acuña L, Basterra LA, Heredero S, SanMartín R (2013) Estimación de la calidad de la madera en rollo de Populus $x$ euramericana mediante ultrasonidos [Estimation of round timber quality of Populus $x$ euramericana by ultrasounds]. Proceedings of $6^{\circ}$ Congreso Forestal Español. June 10-14. Vitoria, Spain, p 11

Chauhan SS, Walker JCF (2006) Variations in acoustic velocity and density with age, and their interrelationships in radiata pine. For Ecol Manag 229:388-394. https://doi.org/10.1016/j.foreco.2006. 04.019

Chen ZQ, Karlsson B, Lundqvist SO, García-Gil MR, Olsson L, Wu HX (2015) Estimating solid wood properties using Pilodyn and acoustic velocity on standing trees of Norway spruce. Ann For Sci 72:499 508. https://doi.org/10.1007/s13595-015-0458-9

Cumbo DW, Smith RL, Becker CW III (2004) Value analysis of lumber produced from small-diameter timber. For Prod J 54(10):29-34

Desponts M, Perron M, DeBlois J (2017) Rapid assessment of wood traits for large-scale breeding selection in Picea mariana [Mill.] B.S.P. Ann For Sci 74:53. https://doi.org/10.1007/s13595-017-0646-X

Díaz-Bravo S, Espinosa M, Valenzuela L, Cancino J, Lasserre JP (2012) Efecto del raleo en el crecimiento y algunas propiedades de la madera de Eucalyptus nitens en una plantación de 15 años [Effect of thinning on growth and some properties of wood of Eucalyptus nitens in a plantation of 15 years old]. Maderas-Cienc Technol
$14(3): 373-388$. https://doi.org/10.4067/S 0718 221X2012005000009

Divós F, Tanaka T (1997) Lumber strength estimation by multiple regression. Holzforschung 51:467-471. https://doi.org/10.1515/hfsg. 1997.51.5.467

Doran M (2012) Biomass resources in the island of Ireland. ICLRD briefing paper series $10: 1-8$

European standard (2002) EN 13183-1. Moisture content of a piece of sawn timber. Part 1: determination by oven dry method. European Committee of Standardization (CEN), Brussels

European standard (2003a) EN 14251. Structural round timber - test methods. European Committee for Standardization (CEN), Brussels, Belgium

European standard (2003b) EN 13556. Round and sawn timber - nomenclature of timber used in Europe. European Committee of Standardization (CEN), Brussels, Belgium

European standard (2012) EN 408:2010+A1. Timber structures. Structural timber and glued laminated timber. Determination of some physical and mechanical properties. European Committee of Standardization (CEN), Brussels, Belgium

European standard (2018) EN 384:2016+A1. Structural timber. Determination of characteristic values of mechanical properties and density. European Committee of Standardization (CEN), Brussels, Belgium

Fundova I, Funda T, Wu HX (2019) Non-destructive assessment of wood stiffness in Scots pine (Pinus sylvestris L.) and its use in forest tree improvement. Forests 10:491. https://doi.org/10.3390/f10060491

Gao S, Wang X, Wiemann MC, Brashaw BK, Ross RJ, Wang L (2017) A critical analysis of methods for rapid and nondestructive determination of wood density in standing trees. Ann For Sci 74:27. https:// doi.org/10.1007/s13595-017-0623-4

Gil-Moreno D (2018) Potential of noble fir, Norway spruce, western red cedar and western hemlock grown for timber production in Great Britain. PhD Dissertation. Edinburgh Napier University. 238 p

Gil-Moreno D, Ridley-Ellis DJ (2015) Comparing usefulness of acoustic measurements on standing trees for segregation by timber stiffness. Proceedings of 19th International Nondestructive Testing and Evaluation of Wood Symposium. September 22-25. Rio de Janeiro, Brazil. pp 378-385

Gonçalves R, Lopes GH, Ornelas NM, Brazolin S, Bertoldo C (2019) Ultrasound test for root and branch wood elastomechanical characterization. Proceedings of 21st International Nondestructive Testing and Evaluation of Wood Symposium. September 24-27. Freiburg im Breisgau, BW, Germany, pp 438-444

Gorman T, Miller B, Kretschmann DE (2016) Wood I beams manufactured from small diameter logs. Proceedings of World Conference on Timber Engineering (WCTE 2016). August 22-25. Vienna, Austria, pp 1250-1257

Grabianowski M, Manley B, Walker JCF (2006) Acoustic measurements on standing trees, logs and green lumber. Wood Sci Technol 40: 2005-2016. https://doi.org/10.1007/s00226-005-0038-5

Haines DW, Leban JM, Herbé C (1996) Determination of Young's modulus for spruce, fir and isotropic materials by the resonance flexure method with comparisons to static flexure and other dynamic methods. Wood Sci Technol 30:253-263. https://doi.org/10.1007/ BF00229348

Hawe J, Short I (2016) Broadleaf thinning in Ireland - a review of European silvicultural best practice. Irish For 73:25-64

Hermoso E, Fernández-Golfín JI, Díez MR, Mier R (2007) Aplicación de los ultrasonidos a la evaluación de las propiedades mecánicas de la madera en rollo de pequeño diámetro [Ultrasound application to evaluation of small round timber mechanic properties]. Inf Constr 59(506):87-95. https://doi.org/10.3989/ic.2007.v59.i506.511

Íñiguez G (2007) Clasificación mediante técnicas no destructivas y evaluación de las propiedades mecánicas de la madera aserrada de coníferas de gran escuadría para uso estructural. [Grading by non- 
destructive techniques and assessment of the mechanical properties of large cross section coniferous sawn timber for structural use]. $\mathrm{PhD}$ Dissertation. ETS de Ingenieros de Montes. Universidad Politécnica de Madrid, Madrid, Spain. 223 p

Íñiguez-González G, Arriaga F, Osuna-Sequera C, Esteban M, RidleyEllis DJ (2019) Nondestructive measurements in reclaimed timber from existing structures. Proceedings of 21 st International Nondestructive Testing and Evaluation of Wood Symposium. September 24-27. Freiburg im Breisgau, BW, Germany, pp 462472

Jayne BA (1959) Vibrational properties of wood as indices of quality. For Prod J 9(11):413-416

Krajnc L, Farrelly N, Harte AM (2019a) The effect of thinning on mechanical properties of Douglas fir, Norway spruce, and Sitka spruce. Ann For Sci 76:3. https://doi.org/10.1007/s13595-018-0787-6

Krajnc L, Farrelly N, Harte AM (2019b) The influence of crown and stem characteristics on timber quality in softwoods. For Ecol Manag 435: 8-17. https://doi.org/10.1016/j.foreco.2018.12.043

Krajnc L, Farrelly N, Harte AM (2019c) Evaluating timber quality in larger-diameter standing trees: rethinking the use of acoustic velocity. Holzforschung 73(9):797-806. https://doi.org/10.1515/hf-20180232

Lasserre JP, Mason EG, Watt MS (2007) Assessing corewood acoustic velocity and modulus of elasticity with two impact based instruments in 11-year-old trees from a clonal-spacing experiment of Pinus radiata D. Don. For Ecol Manag 239:217-221. https://doi. org/10.1016/j.foreco.2006.12.009

Lindström H, Harris P, Nakada R (2002) Methods for measuring stiffness of young trees. Holz Roh Werkst 60:165-174. https://doi.org/10. 1007/s00107-002-0292-2

Lindström H, Reale M, Grekin M (2009) Using non-destructive testing to assess modulus of elasticity of Pinus sylvestris trees. Scand J For Res 24:247-257. https://doi.org/10.1080/02827580902758869

Llana DF, Íñiguez-González G, Arriaga F, Wang X (2016) Time-of-flight adjustment procedure for acoustic measurements in structural timber. Bioresources 11(2):3303-3317. https://doi.org/10.15376/ biores.11.2.3303-3317

Llana DF, Íniguez-González G, Montón J, Arriaga F (2018) In-situ density estimation by four nondestructive techniques on Norway spruce from built-in wood structures. Holzforschung 72(10):871-879. https://doi.org/10.1515/hf-2018-0027

Martínez RD, Balmori JA, Llana DF, Bobadilla I (2020) Wood density determination by drilling chips extraction in ten softwood and hardwood species. Forests 11:303. https://doi.org/10.3390/f1 1040383

Merlo E, Álvarez-González JG, Santaclara O, Riesco G (2014) Modelling modulus of elasticity of Pinus pinaster Ait. in northwestern Spain with standing tree acoustic measurements, tree, stand and site variables. For Syst 23(1):153-166. https://doi.org/10.5424/fs/201423104706

Miller RB, Ilic J (1992) A comprehensive database of common and scientific names of world woods. https://www.fpl.fs.fed.us/search/ commonname_request.php. Accessed 17 March 2019

Mockler N (2013) Physical characterisation and quantification of total above ground biomass derived from first thinnings for wood fuel consumption in Ireland. Master thesis. Waterford Institute of Technology. $131 \mathrm{p}$

Moore JR, Lyon AJ, Searles GJ, Vihermaa LE (2009) The effects of site and stand factors on the tree and wood quality of Sitka spruce growing in the United Kingdom. Silva Fenn 43(3):383-396. https://doi. org/10.14214/sf.195

Moore JR, Lyon AJ, Searles GJ, Lehneke SA, Ridley-Ellis DJ (2013) Within- and between-stand variation in selected properties of Sitka spruce sawn timber in the UK: implications for segregation and grade recovery. Ann For Sci 70:403-415. https://doi.org/10.1007/ s13595-013-0275-y
Mora CR, Schimleck LR, Isik F, Mahon JM Jr, Clark A III, Daniels RF (2009) Relationships between acoustic variables and different measures of stiffness in standing Pinus taeda trees. Can J For Res 39: 1421-1429. https://doi.org/10.1139/X09-062

Niemz P, Bachtiar EV (2017) Moisture-dependent elastic characteristics of wood by means of ultrasonic waves and mechanical test. Proceedings of 20th International Nondestructive Testing and Evaluation of Wood Symposium. September 12-15. Madison, WI, USA. pp 214-221

Ozyhar T (2013) Moisture and time-dependent orthotropic mechanical characterization of beech wood. PhD Dissertation. ETH Zurich, Switzerland, p 126

Pelizan TR (2004) Estudo de propriedades mecânicas de peças roliças de eucalipto citriodora utilizando a técnica de ultra-som [Study of mechanical properties in lemon-scented gum round timber by ultrasound techniques] Master Dissertation. Escola de Engenharia de Sâo Carlos. Universidade de Sâo Paulo, SP, Brazil, p 71

Rais A, Pretzsch H, van de Kuilen JWG (2014) Roundwood pre-grading with longitudinal acoustic waves for production of structural boards. Eur J Wood Prod 72:87-98. https://doi.org/10.1007/s00107-0130757-5

Rais A, Pretzsch H, van de Kuilen JWG (2020) European beech log and lumber grading in wet and dry conditions using longitudinal vibration. Holzforschung. In press. https://doi.org/10.1515/hf-2019-0227

Ross RJ (ed) (2015) Nondestructive evaluation of wood, vol 238 Government Printing Office, Madison, p 169

Ross RJ, McDonald KA, Green DW, Schad KC (1997) Relationship between $\log$ and lumber modulus of elasticity. For Prod J 47(2): 89-92

Ruy M, Gonçalves R, Pereira DM, Lorensani RGM, Bertoldo C (2018) Ultrasound grading of round Eucalyptus timber using the Brazilian standard. Eur J Wood Prod 76:889-898. https://doi.org/10.1007/ s00107-018-1292-1

Sandoz JL (1989) Grading of construction timber by ultrasound. Wood Sci Technol 23:95-108. https://doi.org/10.1007/BF00350611

Sandoz JL (1993) Moisture content and temperature effect on ultrasound timber grading. Wood Sci Technol 27:373-380. https://doi.org/10. 1007/BF00192223

Santaclara O, Merlo E (2011) Acoustic segregation of Pinus pinaster logs for structural lumber production according to strength classes. Proceedings of 17 th International Nondestructive Testing and Evaluation of Wood Symposium. September 14-16, Sopron, Hungary, p 755

Short I, Radford T (2008) Silvicultural guidelines for the tending and thinning of broadleaves. Teagasc, Dublin, Ireland. 30 p. PDF file: https://t-stor.teagasc.ie/handle/11019/25

Simic K, Gendvilas V, O’Reilly C, Harte AM (2019) Predicting structural timber grade-determining properties using acoustic and density measurements on young Sitka spruce trees and logs. Holzforschung 73(2):139-149. https://doi.org/10.1515/hf-20180073

Suryoatmono B (2017) Correction factors in the determination of moduli of elasticity of orthotropic material using ultrasonic longitudinal wave propagation method. Proceedings of 20th International Nondestructive Testing and Evaluation of Wood Symposium. September 12-15. Madison, WI, USA, pp 222-228

Toulmin MJ, Raymond CA (2007) Developing a sampling strategy for measuring acoustic velocity in standing Pinus radiata using the Treetap time of flight tool. N Z J For Sci 37(1):96-111

Tsehaye A, Buchanan AH, Walker JCF (2000) Sorting of logs using acoustics. Wood Sci Technol 34:337-344. https://doi.org/10.1007/ s002260000048

Unterwieser H, Schickhofer G (2007) Pre-grading of sawn timber in green condition. Proceedings of COST E53 conference of quality control for wood and wood products. October 15-17. Warsaw. Poland. 161-166 
Vega A, González L, Fernández I, González P (2019) Grading and mechanical characterization of small-diameter round chestnut (Castanea sativa Mill.) timber from thinning operations. Wood Mater Sci Eng 14(2):81-87. https://doi.org/10.1080/17480272. 2017.1387174

Vihermaa LE (2010) Influence of site factors and climate on timber properties of Sitka spruce (Picea sitchensis (Bong.) Carr.). PhD Dissertation. University of Glasgow. $372 \mathrm{p}$

Villanueva JL (2009) Caracterización mecánica de rollizos de sabina (Juniperus thurifera L.) de Castilla y León. Prueba de clasificación visual y evaluación mediante resonancia [Mechanical characterization of Spanish juniper (Juniperus thurifera L.) round timber from Castilla y León. Visual strength grading and resonance evaluation]. Final Project Degree. E.T.S.I. Agraria. UdL. Lérida. Spain. 65 p

Vössing KJ, Niederleithinger E (2018) Nondestructive assessment and imaging methods for internal inspection of timber. A review. Holzforschung 72(6):467-476. https://doi.org/10.1515/hf-20170122

Vries P, Gard WF (1998) The development of a strength grading system for small diameter roundwood. Heron 43(4):183-197

Wang X (2013) Acoustic measurements on trees and logs: a review and analysis. Wood Sci Technol 47:965-975. https://doi.org/10.1007/ s00226-013-0552-9

Wang X, Ross RJ, Mattson JA, Erickson JR, Forsman JW, Geske EA, Wehr MA (2002) Nondestructive evaluation techniques for assessing modulus of elasticity and stiffness of small-diameter logs. For Prod J 52(2):79-85
Wang X, Ross RJ, Brashaw BK, Punches J, Erickson JR, Forsman JW, Pellerin RF (2004) Diameter effect on stress-wave evaluation of modulus of elasticity of logs. Wood Fiber Sci 36(3):368-377

Wang X, Ross RJ, Carter P (2007) Acoustic evaluation of wood quality in standing trees. Part I. Acoustic wave behavior. Wood Fiber Sci 39(1):28-38

Wessels CB, Malan FS, Rypstra T (2011) A review of measurement methods used on standing trees for the prediction of some mechanical properties of timber. Eur J For Res 130:881-893. https://doi.org/ 10.1007/s10342-011-0484-6

Wolfe R (2000) Research challenges for structural use of small-diameter round timbers. For Prod J 50(2):21-29

Wolfe R, Moseley C (2000) Small-diameter log evaluation for valueadded structural applications. For Prod J 50(10):48-58

Yang JL, Fortin Y (2001) Evaluating strength properties of Pinus radiata from ultrasonic measurements on increment cores. Holzforschung 55:606-610. https://doi.org/10.1515/HF.2001.099

Yin Y, Nagao H, Liu X, Nakai T (2010) Mechanical properties assessment of Cunninghamia lanceolata plantation wood with three acoustic-based nondestructive methods. J Wood Sci 56:33-40. https://doi.org/10.1007/s10086-009-1067-8

Zhang H, Wang X, Su J (2011) Experimental investigation of stress wave propagation in standing trees. Holzforschung 65:743-748. https:// doi.org/10.1515/HF.2011.059

Publisher's note Springer Nature remains neutral with regard to jurisdictional claims in published maps and institutional affiliations. 